\title{
ALEXANDER THE GREAT AND THE “CLASH” OF ANCIENT CIVILIZATIONS
}

\author{
Mădălina STRECHIE \\ University of Craiova, Craiova, Romania \\ madalinastrechie@gmail.com
}

\begin{abstract}
Alexander the Great was not only a great political leader, but also an amazing general. He did not face only armies, but entire civilizations which he forced to merge, following his own example. We believe that his most lasting victory was the Hellenistic civilization, a new civilization that emerged after the "clash of civilizations" that Alexander, the great leader, had opposed, namely the Greek civilization versus the Persian civilization. His war was totally new, revolutionary, both in terms of fighting tactics, weapons, and especially goals. Alexander became the Great because of his ambition to conquer the world from one end to the other. Beginning with the pretext meant to take revenge for the Persian Wars, his expedition to the Persian Empire was in fact a special "clash of civilizations". With Alexander, the West fully demonstrates its expansionist tendencies, conquering at first an empire and civilization after civilization. Thus, in turn, the Greek crusher of the new half-god of war defeated the Phoenician, Egyptian, Persian civilizations (the coordinator of the empire that initiated for the first time the process of assimilation of the defeated ones, namely Persanization).From the military point of view, Alexander the Great was the initiator of the lightning war, of course mutatis mutandis, forming a military monarchy within the conquered civilizations, turning for the first time in history, generals into important politicians, we think here of the Diadochi. Alexander the Great forced the limits beyond human possibilities, beyond the map and beyond fate. He is the most original general of history, precisely in his manner of making war and imposing peace, being the toughest "shock of civilizations".
\end{abstract}

Keywords: Alexander the Great, military revolution, "clash of civilizations", strategy, lightning war.

\section{Introduction}

Alexander of Macedon, rightly called the Great, was a true agent, avant la lettre, for the "clash of civilizations" [1]. Not only did Alexander the Great force civilizations to "clash", but he also created all the conditions for this purpose, causing a strong shock to both civilizations that he forced to face, the Greek civilization, the West, and the Persian civilization, the East.

Alexander the Great began this forcible merging of civilizations with the aim of relating them, giving himself as an example through his marriage to Princess Roxana, a representative of the Persian nobility. Civilizations clashed during his reign as an emperor, they merged for a little while, less politically, but from a cultural point of view. This merging was successful if we think that Hellenism was a consequence of this shock of civilizations, which Alexander the Great fulfilled. Even though his (multicivilized) empire that stretched from Europe to North Africa and Asia (he reached India) did not outlive his founder, the culture of this association, Hellenism, arising from this "clash" survived as proof of "his exceeded dream" [2]. Because this 
"dream", "the longest dream of history" came into being with Alexander the Great [3], the one who wanted to reach the boundaries of the universe, wishing to find out where the "Greek adventure" could get, while imagining another kind of Greek colonization, a global, world one, a forced colonization with the help of weapons, and less with economic means.

\section{Alexander - a political and military leader}

Any "dream", regardless of its amplitude, needs a person to transform it into reality, this extraordinary person was Alexander of Macedon (Macedonia being considered almost barbarian by Athens). He was the son (therefore prince) of Philip II, king of Macedon, and Olympias, the princess of Epirus, thus having an indisputable royal descent. Although his father made a series of revolutions in ancient military technology [4], Philip II setting up the phalanx, a very effective combat unit, Alexander is the one who "sets a pattern of the commander of ancient military history" [5] through all he did to achieve "his dream". In order to put his aspirations into practice, Alexander had to seize power and take his father's place, even if he was the lawful heir to the throne. Gossip suggests that Philip II was helped to die faster, even by Alexander's mother, Olympias (it is said that she poisoned her husband so that the son could seize power) who believed most in his universal dream. However, Alexander of Macedon masterly performed his role as king not only of Macedonia but also of the whole world, as he would later prove through the fulfillment of "his dream", namely the association of antagonistic civilizations, even if this was accomplished through a "clash".

For the king of the Universe, Alexander builds the image of a providential leader who resembles that of an Oriental despot rather than the image of the Greek politician, an inventor of democracy. His mother was his main imagological agent, claiming that Alexander was the son of Zeus, therefore hero, a half-god, the son of the chief of the Greek pantheon, and Alexander was not only the king, the general, but also the "god" [6]. This imagological construction transformed Alexander into an absolute Oriental monarch, who was the messenger of the gods on earth, or the god himself, son of heavens (as was the case with the ancient Chinese ruler).

With this hero image for the West and messenger of the gods on earth for the East, Alexander the Great begins the shock of civilizations, having political and imagological legitimacy, he was the king of the people and the son of Zeus, another Heracles, thus also having a pretext for conquering the Ancient Orient, represented by the Persian civilization, namely the revenge the Greeks had to take for the Persian wars, although this episode of the "clash of civilizations" ended with the victory of the West. Alexander considered that the revenge had not been full, especially because it was not due to him, and by the conquest of the East he thought he would avoid the conflicts between the West and the East in the future, wanting to merge the two civilization axes. This could not be done by a man, but by a hero, god, and military genius. So he started the attack, considering it to be the best defense for the Greeks, an attack that no one had ever done before, with weapons and unique strategies, worthy of a civilization builder.

In his march against the Orient, Alexander ignored the Greeks who questioned his actions, he actually was a "man of extremes" who punished the traitors, whether they were from his or the enemy's camp, he relied on speed in his attacks and was a "charismatic, visionary, tenacious and courageous leader" [7].

As general, Alexander of Macedon is unique, not only by his qualities, by his achievements, but especially by his way of acting in the war, the frontal speed attack being his favorite attack. Alexander had all 
the "talents of a high commander", and his Macedonians had already invented numerous military technologies and structures, all of which had "the natural qualities of a war-trained people: courage, skill, strength, and enthusiasm" [8]. His idea of attack was based on what was called "domination" [9], which he obtained by attacking the enemy in the center, using the unpredictable created in the enemy's camp, the unpredictable that helped him every time.

\section{Alexander the Great - the revolutionary of the military art and builder of civilizations}

Alexander had inherited from his father a very well articulated army, whose basic structure was the phalanx, to which he added an efficient organization and reaction speed in combat, being "a master of mobility" [10]. He was the embodiment of the military leader, having all the military qualities required for a commander: "courage, patience, energy and resilience", he was "bold", he had "the power to predict", "instinct", "strategic vision", he knew how to improvise on the battlefield and was an "opportunist" [11].

The "clash of civilizations", in fact, their transformation, was started by Alexander the Great through a revolution of his army, inherited from his father, but also of the Greek tradition defense doctrine, both revolutions marked forever the European military art and not only. Thus, he first reorganized the Macedonian cavalry, a heavy cavalry, also called the cavalry of the companions - hetairoi - leaving open the selection of new recruits whenever needed. This cavalry, which was a kind of Macedonian elite troop, was endowed by Alexander with "new weapons, instruction, and a new doctrine", mainly based on "the shock the enemy had after they attacked it and found a break" [12]. This cavalry was not very large in number, it had 1800 hetairoi, forming 8 groups (so each group counted about 225 people), Alexander himself being part of one of these groups.

He also reformed the heavy infantry, abandoning the traditional Greek hoplites, the Macedonian phalanx being an infantry specially prepared to take the enemy cavalry out of the game, with their very long spears, called sarissas (4 to $6 \mathrm{~m}$ long), less prepared as a light infantry. He practically adapted the infantry to the cavalry needs to create the breakthrough it needed to attack, a revolutionary military innovation in the ancient world of that time. He did not give up the light infantry, made up of hypaspists, who became a kind of elite hoplites. In addition, the infantry was supported by archers and slingers [13], who gave mobility and rapidity to the army corps led by the great dreamer and general of the ancient world.

Alexander's strategy was to start the attack with the heavy infantry to create breaks in the enemy army, then fight with the light infantry, while giving the final strike with the cavalry [14].

To all this, Alexander the Great added speed, imposing an infernal rhythm on his armies, even forced marches. He was the creator of the lightning war, for he had a flashing speed in both moving and especially attacking, which created a devastating impact on the enemy that became confused at first. However, Alexander the Great practiced the siege of the enemy, as was the case with Tyre, the Phoenician city-state that caused trouble to him for seven months (January-July 332 BC) [15], especially because Alexander defeated the enemy besieged not by the fleet, which was absent since leaving for the conquest of the world, but by genius constructions. He built a platform to reach the position of the city of Tyre, situated on a rock, and thus demonstrating that the inventors of mathematics were the Greeks.

All his Granicus, Issus and Gaugamela victories against the Persians were masterpieces of attack strategy, but Tyre's siege for seven months, which ended with his victory, is the fourth masterpiece of his 
military genius. The lightning war with the Persians of Alexander the Great lasted 11 months, between December 331 and October 330 BC [16], his victories brought him not only a country, but a whole civilization, a multinational empire, for Persia was the leader of the Near East.

At Gaugamela he fought a battle that brought him Asia, leading his 47,000 Greeks against 12,0000 Persians [17], (the ratio being 1 Greek to 2-3 Persians) attacking the core of the Persian army in order to break its unity, (causing chaos) to later slaughter it through the attack of his cavalry of companions. At Issus, Alexander defeated Darius III's cavalry using a central attack and relying on 30,000 mercenaries, with a total of 65,000 men [18], Darius III being killed by the traitors in his camp for the loss of this battle, which turned Alexander into the monarch of Persia and his empire. This victory, too, was a masterpiece of the Alexander's military strategy because the Persians had a very well-equipped cavalry at that time, with scythed chariots, which made it lethal. Alexander the Great took it out of the battle with the help of his heavy infantry equipped with sarissas, and the attack in the center of the Persian army had a major psychological impact, taking the headquarters of the Persian army off the battlefield, in addition to breaking into two the Persian battle line.

To alleviate the shock on the East that fell into his hands in less than a year, Alexander embraced Oriental traditions, proclaiming himself the pharaoh of Egypt, building cities bearing his name, so as to prove that he was chosen by the gods of both the West and the East. He married the Persian princess Roxana in order to secure a smooth governing of the Persian Empire. The civilizations that he, by his own will, made "clash" were bound to kinship, his actions transforming Alexander into a hero in the West and a god in the East (the pharaoh being the son of the gods sent to earth to govern people.) In fact, these political actions proved that Alexander possessed "political wisdom" [19] which, however, infuriated the Greeks, but by conquering the Persian Empire, Alexander was not only the king of Macedonia, he was also the emperor of Persia, therefore he had to act accordingly, especially since the Persians invented the imperial political formation, as well as Persanization, being very tolerant with the defeated ones. He proclaimed himself shahanshah $=$ the King of kings [20], becoming an absolute Oriental monarch, not only the son of Zeus, but also a pharaoh, the shah of Persia, and the despot of Babylon.

Alexander the Great is the first to conquer Afghanistan, its first and last conqueror, precisely through the uniqueness of his strategy. He also built fortresses with his name in Afghanistan, trying the sedentarization of nomads. He passed over the Hindu-Kush Mountains to conquer India [21], perhaps his most ambitious project, "the Greek Adventure" repeating the Aryans' adventure, those who conquered India and transformed it forever, Alexander proving that he had "exceeded his dream".

\section{Conclusions}

Alexander of Macedon was more than Great, a true titan of military art and history of the world, inaugurating what was later called blitzkrieg, also by attacking the enemy right in the center, in the heart of its forces. Through this central attack, he benefited from three advantages: 1 . Destruction of the unit by separating the enemy army, producing breaks through which his army's crusher would penetrate; 2. Annihilation of the headquarters of the enemy army, which was thus out of the battle, unable to communicate decisions; 3 . Psychological impact on the morale of combat troops, on the one hand he created chaos, frightening the enemy, and on the other hand he created the confidence of victory in his troops.

Alexander the Great was truly a half-god, a hero of the whole humanity, shocking both 
the West and the East, he alone produced the most impressive "clash of civilizations". $\mathrm{He}$ forced the two civilizations, often antagonistic, to become related, beginning with himself, through his marriage to the Persian princess Roxana. He was a builder of civilization through all his towns and cities, building his own civilization, a crossbreeding between the two civilizations he "clashed", namely Hellenism, which was more than a Greek civilization, it was equally an Oriental civilization.

Alexander is the Great one, for although the empire he created did not outlive him, something else survived and lasted longer, namely the Hellenistic civilization, a civilization of the border between the West and the East, as he caused the only "clash of civilizations" that resulted in the birth of a new civilization, according to the philosophical principle of coincidentia oppositarum $=$ the union of the antagonistic ones (our transl.). Alexander the Great created for the first time a "multi-civilized" world [22] of two rival civilizations, starting from a "core state" [23], the small kingdom of Macedonia. In the ancient world Alexander remained unique through his achievements, through his "dream", and in the Middle Ages another "dream" came into being from the Asian steppe, a dream which surpassed his aspirations.

\section{References}

[1] Apud Samuel P. Huntigton, Ciocnirea civilizaţiilor şi refacerea ordinii mondiale, traducător Radu Carp, prefaţă Iulia Motoc, Bucureşti, Editura Antet, 1998.

[2] Cf. Benoist-Méchin, Alexandru cel Mare sau visul depășit, 356-323 a Chr., Traducere de Crina Coșoveanu, București, Editura Humanitas, 1994, p. 1.

[3] Ibidem, p. 7.

[4] For the Greek army, see Panagiotis Asimopoulos, "A contribution to study about the defensive and the offensive weapons of Ancient Greeks", in ***Războiul, artei zeilor și a eroilor, volum îngrijit de Mădălina Strechie, Craiova, Editura Universitaria, 2016, pp. 926. For the battle machines of the ancient Greeks, see Panagiotis Asimopoulos, "The siege engines in Ancient Greece: a descriptive approach to their characteristic features", in ***Războiul, artei zeilor și a eroilor, volum îngrijit de Mădălina Strechie, Craiova, Editura Universitaria, 2016, pp. 27-42.

[5] Apud Barry Strauss, Mari comandanți: Alexandru, Hannibal, Cezar și arta conducerii, Traducere de Paul Aneci, Iași, Editura Polirom, 2012, p. 27.

[6] Apud Benoist-Méchin, op. cit., p. 123.

[7] Apud Cormac O'Brien, Declinul imperiilor. De la glorie la ruină. Povestea marilor imperii antice, Traducere din limba engleză de Daniela-Georgiana Arșinel și Ruxandra Apetrei, București, Editura Curtea Veche, 2010, p. 156, pp. 158-161.

[8] Apud Carl von Clausewitz, Despre război, Note și verificarea științifică a textului de general-maior dr. Corneliu Soare, București, Editura Antet XX Perss, no year mentioned, p. 77 , p. 79.

[9] Ibidem, p. 172.

[10] Apud Barry Strauss, op. cit., 61.

[11] Ibidem, p. 61.

[12] Ibidem, pp. 62-63.

[13] Ibidem, p. 63.

[14] Ibidem, p. 63.

[15] Cf. Arthur Weigall, Alexandru Macedon, Traducere de Ileana Zara-Ionescu, București, Editura Artemis, no year mentioned, pp. 187-191

[16] Ibidem, pp. 242-243. 
[17] Cf. Ian V. Hogg, Dicționarul marilor bătălii, Traducere de Ligia Caranfil, București, Editura Artemis, no year mentioned, p. 80.

[18] Ibidem, p. 98.

[19] Apud J. B. Bury, Russell Meiggs, Istoria Greciei până la moartea lui Alexandru cel Mare, Ediția a IV-a (revăzută), Traducere de Diana Stanciu, București, Editura Bic All, 2006, pp. 471-474.

[20] Apud Cormac O'Brien, op. cit., p. 162.

[21] Apud J. B. Bury, Russell Meiggs, op. cit., pp. 479-480.

[22] Samuel P. Huntigton, op. cit., p. 28.

[23] Ibidem, p. 355.

[24] Lévêque, Pierre, Aventura greacă, 2 vol., Traducere de Constanța Tănăsescu, București, Editura Meridiane, 1987.

[25] Paraire, Philippe, Mari lideri ai istoriei mondiale, Traducere: Doina Bodea, no place mentioned, Editura Arc, 1999.

[26] ***The Cambridge History of Greek and Roman Warfare. Volume I. Greek, The Hellenistic World and the Rise of Rome, Edited by Philip Sabin, Hans Van Wees and Michael Witby, Cambridge, Cambridge Histories Online, Cambridge University Press, 2008.

[27] Căzănişteanu, C., Zodian, V., Pandea, A., Comandanţi militari. Dicţionar, Bucureşti, Editura Știinţifică şi Enciclopedică, 1983.

[28] Dana Dinu, Introducere în istoria şi civilizaţia Greciei Antice, Craiova, Editura Universitaria, 2005.

[29] Badea, Simina, "The Greek Inheritance in English", in Receptarea antichităţii grecolatine în culturile europene, ediţia a II-a, Craiova, Editura Universitaria, pp. 47-54.

[30] Van Loon, Hendrik, Willem, Istoria omenirii, Ediţie actualizată și introducere de Robert Sullivan, Traducere din engleză de Cornelia Dumitru, București, Editura Humanitas, 2017. 